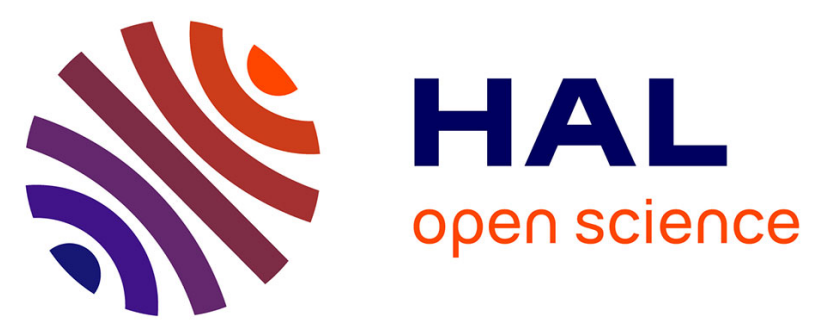

\title{
Agrobacterium rhizogenes-dependent production of transformed roots from foliar explants of pepper (Capsicum annuum): a new and efficient tool for functional analysis of genes
}

Jawad Aarrouf, Patricio Castro Quezada, Simon Mallard, Bernard Caromel, Y Lizzi, Véronique Lefebvre

\section{To cite this version:}

Jawad Aarrouf, Patricio Castro Quezada, Simon Mallard, Bernard Caromel, Y Lizzi, et al.. Agrobacterium rhizogenes-dependent production of transformed roots from foliar explants of pepper (Capsicum annuum): a new and efficient tool for functional analysis of genes. Plant Cell Reports, 2012, 2 (31), pp.391-401. 10.1007/s00299-011-1174-z . hal-01332298

\section{HAL Id: hal-01332298 \\ https://hal.science/hal-01332298}

Submitted on 29 May 2020

HAL is a multi-disciplinary open access archive for the deposit and dissemination of scientific research documents, whether they are published or not. The documents may come from teaching and research institutions in France or abroad, or from public or private research centers.
L'archive ouverte pluridisciplinaire HAL, est destinée au dépôt et à la diffusion de documents scientifiques de niveau recherche, publiés ou non, émanant des établissements d'enseignement et de recherche français ou étrangers, des laboratoires publics ou privés.

\section{(ㅇ)(1) $\$$}

Distributed under a Creative Commons Attribution - NonCommerciall 4.0 International 
Version définitive du manuscrit publié dans / Final version of the manuscript published in : Plant Cell Reports, 2011, OnlineFirst, DOI: 10.1007/s00299-011-1174-z

\section{Agrobacterium rhizogenes-dependent production of transformed roots \\ from foliar explants of pepper (Capsicum annuum):}

A new and efficient tool for functional analysis of genes

\section{J. Aarrouf · P. Castro-Quezada ' S. Mallard 'B. Caromel · Y. Lizzi · V. Lefebvre}

J. Aarrouf $(\bowtie)$. P. Castro-Quezada . S. Mallard . B. Caromel . V. Lefebvre ( $₫)$

Mis en forme : Italien (Italie)

INRA Avignon, UR 1052, Unité de Génétique et Amélioration des Fruits et Légumes, BP 94, Mis en forme : Italien (Italie) 84143 Montfavet cedex, France. veronique.lefebvre@avignon.inra.fr

J. Aarrouf $(\bowtie)$. Y. Lizzi

UAPV Avignon, Laboratoire de Physiologie des Fruits et des Légumes, Pôle Agrosciences, BP 21239, 84916 Avignon cedex 9, France. jawad.aarrouf@univ-avignon.fr 


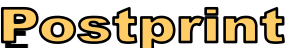

Version définitive du manuscrit publié dans / Final version of the manuscript published in : Plant Cell Reports, 2011, OnlineFirst, DOI: $10.1007 / \mathrm{s} 00299-011-1174-z$

\begin{abstract}
Pepper is known to be a recalcitrant species to genetic transformation via Agrobacterium tumefaciens. Agrobacterium rhizogenes-mediated transformation offers an alternative and rapid possibility to study gene functions in roots. In our study, we developed a new and efficient system for $A$. rhizogenes transformation of the cultivated species Capsicum annuum. Hypocotyls and foliar organs (true leaves and cotyledons) of Yolo Wonder (YW) and Criollo de Morelos 334 (CM334) pepper cultivars were inoculated with the two constructs pBIN-gus and pHKN29-gfp of A. rhizogenes strain A4RS. Foliar explants of both pepper genotypes infected by A4RS-pBIN-gus or A4RS-pHKN29-gfp produced transformed roots. Optimal results were obtained using the combination of the foliar explants with A4RS-pHKN29-gfp. 20.5\% of YW foliar explants and 14.6\% of CM334 foliar explants inoculated with A4RS-pHKN29-gfp produced at least one root expressing uniform GFP. We confirmed by PCR the presence of the rolB and $g f p$ genes in the co-transformed roots ensuring that they integrated both the T-DNA from the Ri plasmid and the reporter gene. We also demonstrated that co-transformed roots of YW and CM334 displayed the same resistance response to Phytophthora capsici than the corresponding untransformed roots. Our novel procedure to produce $C$. annuum hairy roots will thus support the functional analysis of potential resistance genes involved in pepper-P. capsici interaction.
\end{abstract}

Keywords Capsicum annuum Agrobacterium rhizogenes ' Transformation efficiency Green fluorescent protein (GFP) · B-Glucuronidase (GUS) · Phytophthora capsici 
Version définitive du manuscrit publié dans / Final version of the manuscript published in : Plant Cell Reports, 2011, OnlineFirst, DOI: $10.1007 / s 00299-011-1174-z$

\section{Introduction}

Pepper is one of the most cultivated Solanaceae species worldwide. Several diseases caused by oomycetes, fungi, bacteria, nematodes, and viruses can reduce yield and quality of pepper fruits (Black 1991; Djian-Caporalino et al. 2007). A wide variety of microbes invading peppers are soil-borne pathogens. Roots attacked by soil-borne pathogens exhibit a vascular dysfunction and sudden irreversible wilt followed by the death of the plant (Sasser 1977; Khan and Haider 1991; Pegard et al. 2004; Rizzo et al. 2005).

Genetic improvement of plants for resistance to pathogens requires discovering resistance genes and inherent mechanisms involved. For this purpose, the development of a genetic transformation procedure would help to validate the role of discovered genes. However, the recalcitrance of pepper to genetic transformation via Agrobacterium tumefaciens and its poor ability to regenerate in vitro are major drawbacks for functional validation of candidate genes in this species (Wolf et al. 2001).

Concerning root diseases, root transformation with Agrobacterium rhizogenes is a smart alternative to validate the function of candidate genes. A. rhizogenes has a Ri plasmid carrying the rol genes that affect tumorigenesis in plants (Ri for Root-inducing, Chilton et al.1982; Tepfer 1990) and can carry a binary vector containing a candidate gene to be transferred into host explants. The simultaneous integration (co-transformation), into a single explant cell, of the bacterial T-DNA from the Ri plasmid and of the T-DNA from the binary vector, induces proliferation of an hairy root expressing the candidate gene. Root formation at the site of infection is due to a modification of the cell hormonal balances in this organ (Gaudin et al. 1994). When cultured in vitro, A. rhizogenes-transformed roots grow without hormones and are characterized by rapid growth, high branching and plagiotropic development. This method, which implies no regeneration, offers the possibility to study gene functions in roots. It was extensively used to produce secondary metabolites (Hamill and Lidgett 1997) and to study genes specifically involved in root nodulation (Diouf et al. 1995), plant morphology and development (Bandyopadhyay et al. 2007). It served also to validate and analyse the functions of genes conferring resistance to root-specific pathogens (Remeeus et al. 1998; Hwang et al. 2000; Alpizar et al. 2006). Root transformation has previously been carried out on hypocotyls of the related chili pepper species Capsicum frutescens with the three wild strains of A. rhizogenes A5, A13 and 1610 (Sekiguchi et al. 1996; Yamakawa et al. 1998). However, no experiment of A.rhizogenes-mediated transformation was reported with the cultivated species C. annuum. 
Version définitive du manuscrit publié dans / Final version of the manuscript published in : Plant Cell Reports, 2011, OnlineFirst, DOI: 10.1007/s00299-011-1174-z

In this report, we describe a new efficient and convenient method for A. rhizogenesdependent production of co-transformed roots of $C$. annuum. To achieve this goal, first, we compared the efficiency of two A. rhizogenes binary vectors containing either the $g f p$ or the gus reporter gene. Second, we analysed the effect of two plant genotypes (Yolo Wonder and Criollo de Morelos 334) and the origin of the explant on the co-transformation efficiency. Third, we compared the host plant response to the root pathogen Phytophthora capsici in cotransformed and untransformed roots.

\section{Materials and methods}

Plant material and culture conditions

Two cultivars of C. annuum, Yolo Wonder (YW) and Criollo de Morelos 334 (CM334), were used in this study. YW is susceptible to several pathogens, including soil-borne pathogens such as the nematode Meloidogyne incognita and the Oomycetes Phytophthora capsici and P. parasitica, whereas CM334 is resistant (Djian-Caporalino et al. 1999; Bonnet et al. 2007). Seeds were sterilized $20 \mathrm{~min}$ in $2.5 \%$ calcium hypochlorite containing $0.1 \%$ tween 20, rinsed three times in sterile water, and germinated aseptically in Murashige and Skoog (MS) medium (Murashige and Skoog 1962) at $26^{\circ} \mathrm{C}$ under a 16 h-photoperiod (60 $\mu \mathrm{mol} . \mathrm{m}^{-2} . \mathrm{s}^{-1}$ fluorescent white light). Foliar organs (true leaves and cotyledons) and hypocotyls from 21-day-old seedlings were used as explants for A. rhizogenes transformation. All cultures were realized grown in Petri dishes $(9 \mathrm{~cm})$.

Agrobacterium binary vectors

Two constructs in the A. rhizogenes strain A4RS (Jouanin et al. 1986) with different reporter genes were compared in this study for their co-transformation efficiency. The pBIN-gus construct contained the pBIN19 binary plasmid harbouring the gus (uidA) reporter gene coding for $\beta$-glucuronidase under the control of the CaMV 35S promoter (Alpizar et al. 2006). The gus (uidA) bacterial gene from Escherichia coli carried an intron for specific expression in plants. The pHKN29-gfp construct contained a binary vector derived from the pCAMBIA-1300 plasmid by replacing the hygromycin phosphotransferase (hpt) gene with the green fluorescent protein $(g f p)$ reporter gene under the control of the CaMV $35 \mathrm{~S}$ 


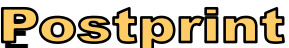

Version définitive du manuscrit publié dans / Final version of the manuscript published in : Plant Cell Reports, 2011, OnlineFirst, DOI: 10.1007/s00299-011-1174-Z

promoter (Niwa et al. 1999). The A4RS strain was derived from the wild strain A4 modified for resistance to rifampycin and spectinomycin antibiotics (Jouanin et al. 1986).

Transformation procedure

A4RS-pBIN-gus (Alpizar et al. 2006) and A4RS-pHKN29-gfp (Niwa et al. 1999, Kumagai and Kouchi 2003) were grown overnight $\left(28^{\circ} \mathrm{C}, 120 \mathrm{rpm}\right)$ on Mannitol Yeast extract casAminoacids (MYA) (Tepfer and Casse-Delbart 1987, M. Tepfer, pers. comm.) and Lysogeny Broth (LB) liquid medium, respectively, with appropriate antibiotics. Hypocotyls, cotyledons, and young true leaves from 21-day-old seedlings were used as explants for transformation. Cotyledons and leaves were cut transversely into four equal pieces. Explants were incubated for $20 \mathrm{~min}$ in A. rhizogenes suspension adjusted to O.D. $600=0.3$ in $1 / 2 \mathrm{MS}$ medium with $0.9 \mathrm{mg} . \mathrm{L}^{-1}$ thiamin and $39 \mathrm{mg} . \mathrm{L}^{-1}$ acetosyringone. After drying, explants were placed on filter paper soaked with $1 / 2 \mathrm{MS}$ liquid medium with $0.9 \mathrm{mg} . \mathrm{L}^{-1}$ thiamin and $39 \mathrm{mg} . \mathrm{L}^{-}$ ${ }^{1}$ acetosyringone. After two days in the dark at $18^{\circ} \mathrm{C}$, explants were transferred to $1 / 2 \mathrm{MS}$ solid medium with cefotaxime $\left(500 \mathrm{mg} . \mathrm{L}^{-1}\right)$ in the dark at $24^{\circ} \mathrm{C}$. Uninfected explants (control) were cultured under the same conditions, except for the inoculum that was substituted by $1 / 2 \mathrm{MS}$ liquid medium.

Characterization of transgenic roots

GUS and GFP expressions were visualized on the roots formed after co-culture with A. rhizogenes. For GUS expression, roots were vacuum-infiltrated for $10 \mathrm{~min}$ in a solution containing $50 \mathrm{mM}$ phosphate buffer $\mathrm{pH} 6.5$ and $1 \mathrm{mM}$ 5-bromo-4-chloro-Indoyl-3glucuronide (X-gluc), then incubated for $24 \mathrm{~h}$ at $37^{\circ} \mathrm{C}$ in dark. The $\beta$-glucuronidase activity was detected by a blue compound in the transformed roots (Jefferson 1987). Expression of the gfp gene in roots was analyzed weekly with a stereo-microscope MZ FLIII (Leica) equipped with a blue-light source and a Leica GFP plus filter set $(\lambda$ ex $=480 / 40 ; \lambda$ em $=$ $510 \mathrm{~nm}$ LP barrier filter). Photographic images were captured using a Leica automatic camera.

Oomycete material and artificial root inoculation by $P$. capsici 
Version définitive du manuscrit publié dans / Final version of the manuscript published in : Plant Cell Reports, 2011, OnlineFirst, DOI: 10.1007/s00299-011-1174-z

The highly aggressive isolate Pc197 of $P$. capsici described by Bonnet et al. (2007) was used to inoculate roots. Mycelium was grown on V8 juice (Campbell) agar medium $\left(22^{\circ} \mathrm{C}, 12 \mathrm{~h}\right.$ fluorescent light and $12 \mathrm{~h}$ darkness). Mycelium plugs (4 mm diameter) were taken off at the periphery of 5-7 day-old Petri dish cultures. Untransformed and co-transformed roots $(5 \pm 1$ cm-long) of YW and CM334 genotypes were isolated and transferred on MS medium without sugar in the dark at $24^{\circ} \mathrm{C}$. The untransformed roots used in this experiment were adventitious roots that developed on untransformed control hypocotyls. The co-transformed roots were excised from foliar organs transformed with the A. rhizogenes strain A4RSpHKN29-gfp and checked for GFP-fluorescence. After 48 hours, the root pathology test was performed by depositing a mycelium plug on the root tip. The purpose of MS medium without sugar was to prevent an excessive development of $P$. capsici on the medium in order to favour its development on roots. Thirty co-transformed plus and thirty untransformed roots per host genotype were used to follow the evolution of the length of root necrosis induced by $P$. capsici during 6 days after inoculation. Then, five co-transformed root tips per host genotype were excised at 24,48 and $72 \mathrm{~h}$ after inoculation for conducting histological studies.

Histological study

Hypocotyl explants and inoculated co-transformed root tips of YW and CM334 were immersed in a cold fixative constituted by formalin-acetic acid-alcohol $(1: 1: 8 \mathrm{~V} / \mathrm{V} / \mathrm{V})$ during $48 \mathrm{~h}$ at $4^{\circ} \mathrm{C}$, rinsed in distilled water, and stored in $70 \%$ ethanol until required. They were then dehydrated in an ethanol series and embedded in resin (Kit Technovit 7100, Wehrheim, Germany). Sections ( $5 \mu \mathrm{m}$ thickness) were serially cut using a Leica microtome, collected on microscope slides and allowed to dry (Aarrouf et al. 2008). Slides with hypocotyl sections were stained with $0.5 \%$ aqueous Toluidine Blue. Slides with root sections were stained to visualize polysaccharides and proteins using periodic acid-Schiff's reagent (PAS) and naphthol blue black procedures, respectively (Aarrouf et al. 2008). Slides were observed with a light microscope (Optiphot-2, Nikon) and photographic images were captured using a Leica automatic camera.

Experimental design and statistical analysis

We performed three independent experiments to study the effects of the explant origin, the pepper genotype and the binary vector carried by the A. rhizogenes strain on the genetic 
Version définitive du manuscrit publié dans / Final version of the manuscript published in : Plant Cell Reports, 2011, OnlineFirst, DOI: $10.1007 / s 00299-011-1174-z$

transformation efficiency. The first and the second experiments aimed to determine the suitability of hypocotyls versus foliar organs (cotyledons and leaves) as explants for the cotransformation procedure. In these two experiments together, 30 to 43 hypocotyl explants were used per combination of strain $x$ genotype. The three experiments were used as replicates to analyse by chi-square (5\% significance level) the effect of two explanatory factors: the "A. rhizogenes binary vector" (pBIN-gus vs. pHKN29-gfp) and the "pepper genotype" (YW vs. CM334) on foliar organs only. For these three experiments together, 198 to 235 foliar explants were used per combination of strain $\mathrm{x}$ genotype. The first and the second experiments also aimed to determine the suitability of hypocotyls versus foliar organs (cotyledons or leaves) as explants for the transformation procedure. In these two experiments together, 30 to 43 hypocotyl explants were used per combination of strain $\mathrm{x}$ genotype.

Expression of the reporter genes, gus or $g f p$, was used to identify co-transformed roots. The efficiency of co-transformation was calculated as the percentage of inoculated explants that produced at least one GUS or GFP-positive root, 10 weeks after co-culture.

Statistical analyses were performed using the R software, version 2.9.0 (2009). The data were analysed by logistic regression with a categorical response of either success or failure. An explant regenerating at least one GUS or GFP-positive root was considered as a success, whereas an explant without GUS or GFP-positive root was considered as a failure. Significance of "experiment", "organ", "A. rhizogenes binary vector" and "pepper genotype" explanatory factors and significance of all interactions between of both factors were investigated by Generalized Linear Models (GLM).

Detection of rolB, virD and gfp genes in transformed hairy roots

DNA was extracted from $10 \mathrm{mg}$ fresh weight of tissue taken from transformed hairy roots as described by Fulton et al. (1995). PCR amplifications were performed separately with the primers specific to the $\mathrm{Ri}$ plasmid gene rolB located in the T-DNA (5'GCTCTTGCAGTGCTAGATTT and 5'-GAAGGTGCAAGCTACCTCTC), to the Ri plasmid virulence gene virD outside the T-DNA (5'-ATGTCGCAAGGCAGTAAG and 5'CAAGGAGTCTTTCAGCATG) and to the reporter gene gfp (5' GCAAGACCCTTCCTCTATATAAG and 5'-CGTCCAGCTCGACCAGGATG). Amplifications were done in a $25 \mu \mathrm{l}$ final reaction volume, with $5 \mu \mathrm{L} 5 \mathrm{X}$ buffer (Promega, France), $1.5 \mathrm{mM} \mathrm{MgCl}$ (Promega, France), $0.2 \mu \mathrm{M}$ of each primer, $0.16 \mu \mathrm{M}$ of each dNTP, $20 \mathrm{ng}$ of DNA template, and 0.25 unit of GoTaq polymerase (Promega, France). PCR 
Version définitive du manuscrit publié dans / Final version of the manuscript published in : Plant Cell Reports, 2011, OnlineFirst, DOI: 10.1007/s00299-011-1174-z

conditions were an initial denaturation for $4 \mathrm{~min}$ at $94^{\circ} \mathrm{C}, 35$ cycles of $30 \mathrm{sec}$ at $94^{\circ} \mathrm{C}, 30 \mathrm{sec}$ at the respective annealing temperature $\left(50^{\circ} \mathrm{C}\right.$ for $\operatorname{rolB}$ and $\operatorname{virD}$, and $60^{\circ} \mathrm{C}$ for $\left.\mathrm{gfp}\right)$ and 20 sec at $72^{\circ} \mathrm{C}$, and one cycle of final extension for $5 \mathrm{~min}$ at $72^{\circ} \mathrm{C}$. PCR products were separated by standard agarose gel electrophoresis and visualised by fluorescence under UV light after ethidium bromide staining.

\section{Results}

Table 1 summarizes our results and shows that very different reactivity values were obtained depending on the type of organ, type of plant genotype, and type of construct carried by $A$. rhizogenes.

Agrobacterium-transformation of hypocotyl explants

Hypocotyl explants from YW and CM334 genotypes were inoculated with A4RS-pBIN-gus or A4RS-pHKN29-gfp. The first adventitious roots were initiated about 3 weeks after coculture. Between 35 and $79 \%$ of explants induced roots 10 weeks after A. rhizogenes inoculation. However, most of the roots were not produced at the cut edge of hypocotyls (Fig. 1A). Visualization of GFP fluorescence and hHistochemical GUS assays showed that YW and CM334 hypocotyls produced only occasionally GUS and GFP positive roots (0 to $7 \%$ of explants were actually co-transformed, Fig. 1A, B). In the absence of A. rhizogenes, non-transgenic adventitious roots also developed along the whole hypocotyl of 30 to $74 \%$ of explants (Fig. 1F, I); moreover, they were rarely initiated from wounded tissue. We speculated that the hypocotyl anatomy promotes root formation without Agrobacteriumtransformation. Histological examination revealed that the organization of YW and CM334 hypocotyls is very similar to the root structure. Cross sections of hypocotyls showed an epidermis, a larger cortical parenchyma than observed in shoots, and a vascular cylinder (Fig. 1C). Adventitious roots in inoculated or uninoculated hypocotyls were initiated near the vascular cylinder adjacent to protoxylem as in the case of root branching. Thus, due to their ability to develop roots spontaneously, pepper hypocotyl explants are not appropriate for genetic transformation via $A$. rhizogenes.

Agrobacterium-transformation of foliar explants 
Version définitive du manuscrit publié dans / Final version of the manuscript published in : Plant Cell Reports, 2011, OnlineFirst, DOI: 10.1007/s00299-011-1174-z

In the case of foliar organs (cotyledons and leaves), GLM analyses did not reveal experiment effect $(\mathrm{P}=0.214)$, nor interaction between experiment and other factors $(\mathrm{P}=0.131$ with genotypes, $\mathrm{P}=0.842$ with construct). Data from experiments $1,2, \& 3$ were merged for further analyses. neoformed Hhairy roots varied from 29 to 59\% (average of experiments 1, 2 \& 3) of infected explants depending on the combination of construct $x$ plant genotype (mean of 45\% (398/866) for experiments 1, $2 \& 3$ together) (Fig. 1D, E, G, H). In parallel, root formation was never observed on uninfected foliar explants (Fig. 1F, I). Our results support the fact that the formation of co-transformed roots on foliar explants resulted from a morphogenetic response attributable to the integration into the pepper genome of the rol genes of the Ri plasmid from A. rhizogenes. Observed adventitious roots grew rapidly with emerging lateral branches in hormone-free medium showing a typical hairy root phenotype. Integration of the reporter gene was checked by GUS staining or by visualization of GFP fluorescence. GUS expression or GFP fluorescence were observed locally one week after $A$. rhizogenes inoculation (Fig. 2A, E), and the co-transformed roots were initiated after five weeks (Fig 2B, F). After 10 weeks of culture, $285 \%$ (112/398) of $45 \%$ of explants producing that showed neoformed hairy roots were co-transformed because they actually expressed GUS or GFP (Fig. 2C, D, G, H). Our results show that foliar explants are better adapted to transformation than hypocotyls. As leaves and cotyledons were counted separately in experiments 2 and 3, we also observed that the leaves showed a better co-transformation efficienciesy than the hypocotyls, whatever the combination of construct $\mathrm{x}$ plant genotype $(\mathrm{P}=0.001)$.

Effect of the A. rhizogenes construct and the plant genotypes on the co-transformed root cotransformation efficiency transformation

The construct and genotype effects were significant ( $\mathrm{p}<0.0001$ and, $\mathrm{p}=0.035$, respectively). The mean percentage of foliar explants producing at least one GUS- or GFP-positive root (co-transformed) varied from $4.6 \%$ to $20.5 \%$ depending on the A. rhizogenes construct and the plant genotype (Table 1). No significant interaction between the $A$. rhizogenes construct and the pepper genotype was detected $(\mathrm{p}=0.992)$.

The percentage of foliar organs producing at least one root expressing a reporter gene is significantly higher $(\mathrm{p}<0.0001)$ in explants transformed with A4RS-pHKN29-gfp in both genotypes compared to explants transformed with A4RS-pHKN29-gus. In the YW genotype, $20.5 \%$ and $7.0 \%$ of foliar explants were co-transformed with A4RS-pHKN29-gfp and A4RS- 
Version définitive du manuscrit publié dans / Final version of the manuscript published in : Plant Cell Reports, 2011, OnlineFirst, DOI: 10.1007/s00299-011-1174-z

pBIN-gus, respectively $(\mathrm{p}=0.0001)$. In the CM334 genotype, $14.6 \%$ and $4.6 \%$ of foliar explants were co-transformed with A4RS-pHKN29-gfp and A4RS-pBIN-gus, respectively $(p=0.0005)$. In addition, the expression level of the reporter genes varied along the transformed roots. GUS expression was only seen in the root tips (Fig. 2C, D), whereas GFP expression was uniform all along entire transformed roots (Fig. 2G, H). Our data clearly demonstrated that the pHKN29-gfp construct is more efficient than the pBIN-gus construct for genetic transformation of pepper via A. rhizogenes (Table 1). In addition, analysis of GFP expression is more convenient than GUS detection because it is non-destructive.

For each construct, we observed that explants from the pepper genotype YW had a trend to produce more co-transformed roots than explants from CM334, but differences awere not significant ( $p=0.0845$ for GFP-positive roots, $p=0.3141$ for GUS-positive roots).

Confirmation of genetically co-transformed roots by polymerase chain reaction (PCR)

GFP or GUS-negative hairy roots were observed on foliar explants infected by both A. rhizogenes constructs, while they were plagiotropic, exhibited rapid growth and formed lateral branches on the hormone free medium. The lack of reporter gene expression in these transformed hairy roots could be due to the lack of co-transfer of the reporter gfp or gus genes from the binary vector with the rol genes from the Ri-plasmid T-DNA.

We established a PCR method for determining the genotype of hairy roots obtained after infection with A4RS-pHKN29-gfp A. rhizogenes strain. Our method was designed to test for the presence of T-DNA genes transferred from the Ri plasmid (rolB) and the binary vector ( $g f p$ ), as well as to rule out artefacts caused by A. rhizogenes contamination (indicated by the presence of the virD gene). PCR analyses performed on GFP-positive roots systematically led to the amplification of the rolB and $g f p$ fragments (Fig. 3). Amplifications demonstrated the presence of the rolB and $g f p$ genes and consequently, the integration of the Ri T-DNA and of the binary plasmid T-DNA into the GFP-positive co-transformed roots. By contrast, only the rolB gene was amplified with DNA from GFP-negative hairy roots (Fig. 3). This result demonstrated that the co-transfer of T-DNA from both plasmids did not occur in GFPnegative roots and that A.rhizogenes transferred only Ri-plasmid T-DNA in roots without GFP expression. No PCR product was amplified with the virD primers, using DNA from all the transformed or co-transformed roots tested. This result confirmed that the detection of rolB or/and gfp genes in hairy roots was not due to a contamination by A. rhizogenes. 


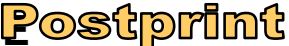

Version définitive du manuscrit publié dans / Final version of the manuscript published in : Plant Cell Reports, 2011, OnlineFirst, DOI: $10.1007 / \mathrm{s} 00299-011-1174-z$

Resistance response of co-transformed and untransformed roots to $P$. capsici infection

The application of mycelium plugs of $P$. capsici on in vitro roots provoked necroses that have evolved continuously over the six days of observation after inoculation. At the $6^{\text {th }}$ dpi (days-post-inoculation), the lengths of the necroses were significantly longer in YW than in CM334, in both co-transformed and untransformed (control) roots (Fig. 4). We also demonstrated that the A. rhizogenes-mediated transformation did not change the host plant response to $P$. capsici. Both untransformed and co-transformed roots of CM334 exhibited a partial resistance to $P$. capsici.

Figure 5 shows longitudinal sections of $P$. capsici-inoculated co-transformed roots at 24 , 48 and 72 hpi (hours-post-inoculation). The co-transformed root tissues of YW were colonized by $P$. capsici 24 hpi, and hyphae emerged in most of the intercellular spaces. At 48 hpi and $72 \mathrm{hpi}$, the hyphae invaded the intracellular spaces of the root tissues, and a number of haustoria formed in host cells. Cortical parenchyma cells became shrunken and partly deformed, and plasma membranes of infected cells were ruptured and progressively plasmolysed. In co-transformed roots of CM334, hyphae rarely progressed in tissues, and the plant cell structure remained intact. These observations indicate that $A$. rhizogenes-mediated transformation did not modify the histological response of YW and CM334 host plant to P. capsici infection.

\section{Discussion}

Pepper is a recalcitrant species to genetic transformation via A. tumefaciens. The functional validation of candidate genes involved in the interaction between pathogens and plant roots is feasible using roots transformed by A. rhizogenes (Cai et al. 1997; Remeeus et al. 1998; Kifle et al. 1999; Hwang et al. 2000; Alpizar et al. 2006; Chattopadhyay et al. 2011). We developed a new, efficient and convenient method for $A$. rhizogenes-dependent production of transformed roots from C. annuum. Three major parameters were tested: the host-plant genotype, the explant type and the construct carried by A. rhizogenes strain A4RS. Indeed, the success of genetic transformation of plant material is typically highly dependent on these parameters and on culture conditions (Spiral et al. 1993; Christey 2001; Baranski et al. 2006; Chovelon et al. 2008).

In our study, the mean co-transformation efficiency (number of co-transformed explants/number of infected explants) of C. annuum widely varied from $0 \%$ to $20.5 \%$ 
Version définitive du manuscrit publié dans / Final version of the manuscript published in : Plant Cell Reports, 2011, OnlineFirst, DOI: $10.1007 / s 00299-011-1174-z$

according to the organ (hypocotyl or foliar explants), the host-plant genotype and the $A$.

rhizogenes construct used (Table 1). This level of variability was also reported in other plant species such as coffee (Alpizar et al, 2006) and Saponaria vaccaria (Schmidt et al. 2007). In C. annuum, we obtained the highest transformation efficiency with foliar explants of YW infected by A4RS-pHKN29-gfp and the lowest with hypocotyls of YW infected by A4RSpBIN-gus (Table 1).

We showed that infected and uninfected hypocotyl explants spontaneously produced roots, contrary to uninfected foliar explants. Adventitious roots were also obtained from uninfected hypocotyls (control) in other species such as Saponaria vaccaria and Brassica oleracea (Oldacres et al. 2005; Schmidt et al. 2007). Our anatomical study of pepper hypocotyls demonstrated that roots are initiated near the vascular cylinder of infected or uninfected explants, as in the case of root branching. In addition, hypocotyl explants produced only occasionally GFP- and GUS-positive roots. Hypocotyl explants were thus considered unsuitable for genetic transformation via A. rhizogenes in pepper.

GFP-positive and GUS-positive roots were obtained from foliar explants infected by A. rhizogenes. In both genotypes YW and CM334, better transformation efficiencies were obtained with the A4RS-pHKN29-gfp than with the A4RS-pBIN-gus. Genetic transformation of plant material is typically highly dependent on cultivar and plasmid construct (Christey 2001, Baranski et al. 2006, Schmidt et al. 2007). All the tissue of GFP-positive roots exhibited intense fluorescence. In contrast, variability in the spatial distribution of GUS expression was observed in transformed roots by A4RS-pBIN-gus. This heterogeneous staining pattern has often been observed with the gus reporter gene (Terada and Shimamoto 1990; Diouf et al. 1995; Alpizar et al. 2006). The gGus gene is preferentially expressed in root tip meristems. The efficiency and regularity of transformation by A4RS-pHKN29-gfp was reported in other species such as Lotus japonicus and Allocasuarina verticillata (Kumagai and Kouchi 2003; Gherbi et al. 2008). The two A. rhizogenes strains used in our work differ exclusively in their binary vector. A4RS-pHKN29-gfp contains the pHKN29 binary vector, which derives from the pCAMBIA-1300 vector in which the hpt II gene has been replaced by the gfp gene (Niwa et al. 1999). A4RS-pBIN-gus contains the pBIN19 binary vector in which the gus gene, interrupted by an intron of 189 base pairs, was inserted (Alpizar et al. 2006). Thus, both binary vectors differ in their T-DNA part as well as in their backbone (vector sequences outside the T-DNA). The T-DNA of pBIN-gus binary vector is 5550 base pairs long whereas the T-DNA of pHKN29-gfp is only 2040 base pairs long. It has previously been reported that long T-DNAs are more difficult to transfer into the host
Commentaire [PO1]: I think this needs further clarification in the statement to indicate from which experiments these data efficiency

Also, for foliar explants (P9L11) you

indicated $25 \%$ of the hairy roots were

cotransformed, which seems to be inconsistent with the figure in this sentence. 
Version définitive du manuscrit publié dans / Final version of the manuscript published in : Plant Cell Reports, 2011, OnlineFirst, DOI: $10.1007 / s 00299-011-1174-z$

genome than shorter T-DNAs (Hamilton 1997; Frary and Hamilton 2001), and that the TDNA size could affect the transformation efficiency. pCAMBIA vector series and their derivatives, such as pHKN29-gfp, carry the pVS1 origin of replication for high stability in Agrobacterium, even in the absence of selection pressure by the appropriate antibiotic. In contrast, pBIN19 and its derivatives carry the IncP $\alpha$ origin of replication, which ensures less stability in Agrobacterium. It has been reported that pBIN19 is rapidly lost from A. tumefaciens in the absence of selection (Bevan 1984). In our experiment, as usually reported in the literature, explants were co-cultured with A. rhizogenes without antibiotics. Thus, the lower efficiency of the A4RS-pBIN-gus A. rhizogenes construct may be due to both factors: the larger size of the T-DNA and/or the loss of the binary vector due to the origin of replication of the vector backbone.

It should be noted that all adventitious roots obtained from foliar explants infected by both A. rhizogenes strains did not express GUS or GFP; however they were all plagiotropic, exhibited rapid growth and formed lateral branches on the hormone free medium. Several authors reported that the integration of rol genes from the Ri-plasmid T-DNA and T-DNA from the binary vector is independent during the transformation process (Shahin et al. 1986; Kumar et al. 2005). The lack of GFP or GUS expression in some hairy roots transformed by A4RS-pHKN29-gfp or A4RS-pBIN-gus may result from the integration of rol genes involved in auxin synthesis without the co-transfer of the gfp or gus reporter genes from the binary vector. We established a PCR method for determining the genotype of hairy roots obtained by our method. We only amplified the rolB gene from DNA of GFP-negative hairy roots. However, PCR analyses performed on GFP-positive roots confirmed the co-transfer of the rolB and $g f p$ genes.

A. rhizogenes-transformed roots proliferated after excision from the explants in media devoid of growth regulators. This autonomy is related to the integration and expression in transformed cells of aux and rol genes from the Ri plasmid that enable the production of endogenous auxin (Nilsson and Olsson 1997). However, the plant growth hormone auxin has long been recognized as a regulator of plant defence. Because many plant pathogenic microorganisms produce auxin during their interactions with plants, this hormone is suspected to increase plant susceptibility (Kazan and Manners 2009; Fu et al. 2011). For functional validation of genes involved in root-pathogen interaction, it was thus necessary to verify if $A$. rhizogenes-transformed roots exhibit a similar phenotype as the genotype from which they were derived. Our data clearly demonstrated that YW transformed roots remained 


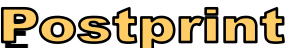

Version définitive du manuscrit publié dans / Final version of the manuscript published in : Plant Cell Reports, 2011, OnlineFirst, DOI: 10.1007/s00299-011-1174-z

susceptible, and CM334 transformed roots remained partially resistant to $P$. capsici, as it has been shown for roots from untransformed cuttings.

In conclusion, we have developed a new and highly efficient protocol for A. rhizogenesmediated transformation of two varieties of $C$. annuum. The best co-transformation efficiency was obtained for both genotypes with the combination of the foliar explants and the A4RS-pHKN29-gfp construct. Hairy root culture has significant advantages such as rapid growth and reproducibility, and sustained maintenance of co-transformed roots is possible by vegetative propagation. This approach based on A. rhizogenes will support an intensive study of host-pathogen interactions and functional analysis of potential resistance genes. Moreover, this is particularly well adapted to RNAi-based approaches to study gene function.

Acknowledgments We thank Hervé Etienne (CIRAD, Montpellier, France) and Claudine Franche (IRD, Montpellier, France) for the generous gift of the A. rhizogenes A4RS strain carrying pBIN-gus and pHKN29-gfp, respectively.

This work was financially supported by the Genoplante Project PhytoSol-2 that resides under the ANR call. Stéphanie Mallard received a fellowship funded by the ANR, Patricio Castro received a fellowship funded by the Secreteria Nacional de Cienca y Tecnologia del Ecuador (SENACYT) from Ecuador. 


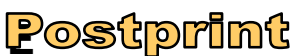

Version définitive du manuscrit publié dans / Final version of the manuscript published in : Plant Cell Reports, 2011, OnlineFirst, DOI: $10.1007 / \mathrm{s} 00299-011-1174-z$

Table 1: Co-tTransformation efficiency of different organs from two host-plant genotypes inoculated with two different binary vectors inserted in the A. rhizogenes strain A4RS, or mock inoculated.

\begin{tabular}{|c|c|c|c|c|c|c|c|c|c|c|}
\hline \multirow[b]{2}{*}{ Organ explant } & \multirow[b]{2}{*}{ Experiment } & \multirow[b]{2}{*}{$\begin{array}{c}\begin{array}{c}\text { Host- } \\
\text { plant } \\
\text { genotype }\end{array} \\
\end{array}$} & \multicolumn{3}{|c|}{ Inoculation with A4RS-pBIN-gus strain } & \multicolumn{3}{|c|}{ Inoculation with A4RS-pHKN29-gfp strain } & \multicolumn{2}{|c|}{ Mock inoculation } \\
\hline & & & $\begin{array}{c}\mathrm{Nb} \text { of } \\
\text { explants }\end{array}$ & $\begin{array}{c}\% \pm \text { SD of } \\
\text { explants that } \\
\text { showed } \\
\text { neoformed hairy } \\
\text { roots } \\
\end{array}$ & $\begin{array}{c}\% \pm \text { SD of } \\
\text { explants that } \\
\text { showed } \\
\text { co-transformed } \\
\text { roots } \\
\end{array}$ & $\begin{array}{c}\mathrm{Nb} \text { of } \\
\text { explants }\end{array}$ & $\begin{array}{c}\% \pm \text { SD of } \\
\text { explants that } \\
\text { showed } \\
\text { neoformed hairy } \\
\text { roots } \\
\end{array}$ & $\begin{array}{c}\% \pm \text { SD of } \\
\text { explants that } \\
\text { showed } \\
\text { co-transformed } \\
\text { roots } \\
\end{array}$ & $\begin{array}{c}\mathrm{Nb} \text { of } \\
\text { explants }\end{array}$ & $\begin{array}{c}\% \pm \text { SD of } \\
\text { explants that } \\
\text { showed } \\
\text { neoformed hairy } \\
\text { roots } \\
\end{array}$ \\
\hline \multirow[t]{2}{*}{ Hypocotyl } & \multirow[t]{2}{*}{ Exp. $1 \& 2$} & YW & 30 & $79.0 \pm 11.0 \%$ & $0.0 \pm 0.0 \%$ & 35 & $35.0 \pm 2.0 \%$ & $5.0 \pm 7.0 \%$ & 30 & $74.0 \pm 15.0 \%$ \\
\hline & & CM334 & 43 & $51.0 \pm 5.0 \%$ & $5.0 \pm 7.0 \%$ & 35 & $63.0 \pm 42.0 \%$ & $7.0 \pm 10.0 \%$ & 35 & $30.0 \pm 8.0 \%$ \\
\hline \multirow[t]{2}{*}{ Foliar explant } & \multirow[t]{2}{*}{ Exp. 1, $2 \& 3$} & $\mathrm{YW}$ & 198 & $47.8 \pm 10.2 \%$ & $7.0 \pm 3.8 \%(b)$ & 223 & $59.5 \pm 11.6 \%$ & $20.5 \pm 8.8 \%$ (a) & 110 & $0.0 \pm 0.0 \%$ \\
\hline & & CM334 & 208 & $29.1 \pm 6.2 \%$ & $4.6 \pm 0.7 \%(\mathrm{c})$ & 235 & $47.5 \pm 19.8 \%$ & $14.6 \pm 1.5 \%$ (a) & 103 & $0.0 \pm 0.0 \%$ \\
\hline \multirow[t]{2}{*}{ Leaf } & \multirow[t]{2}{*}{ Exp. $2 \& 3$} & YW & 68 & $68.5 \pm 13.0 \%$ & $10.4 \pm 2.9 \%$ & 66 & $78.0 \pm 12.7 \%$ & $42.4 \pm 3.54 \%$ & 51 & $0.0 \pm 0.0 \%$ \\
\hline & & CM334 & 67 & $38.7 \pm 1.1 \%$ & $6.1 \pm 1.1 \%$ & 82 & $48.5 \pm 19.0 \%$ & $20.6 \pm 9.1 \%$ & 41 & $0.0 \pm 0.0 \%$ \\
\hline \multirow[t]{2}{*}{ Cotyledon } & \multirow[t]{2}{*}{ Exp. $2 \& 3$} & YW & 65 & $36.8 \pm 3.5 \%$ & $7.8 \pm 2.0 \%$ & 80 & $45.0 \pm 11.3 \%$ & $18.8 \pm 4.9 \%$ & 27 & $0.0 \pm 0.0 \%$ \\
\hline & & CM334 & 94 & $35.1 \pm 0.0 \%$ & $4.6 \pm 1.8 \%$ & 102 & $48.4 \pm 19.0 \%$ & $9.8 \pm 2.8 \%$ & 35 & $0.0 \pm 0.0 \%$ \\
\hline
\end{tabular}

Note: Co-tTransformation efficiency was assessed 10 weeks after co-culture with A. rhizogenes. For each 'Organ x Host-plant genotype $\mathrm{x}$ A. rhizogenes construct' combination, the experiment numbers, the number of explants and the percentage and standard deviation (SD) of explants producing neoformed hairy roots, GUS-positive roots and GFP-positive roots (co-transformed) are indicated. In the 3 experiments, foliar explants included leaves and cotyledons together. Leaves and cotyledons were separately counted in Experiments 2 and 3 . Values with different letters ( $\mathrm{a}, \mathrm{b}$, or $\mathrm{c}$ ) are significantly different at $\mathrm{P} \leq 0.05$ (Newman-Keuls test). 
Version définitive du manuscrit publié dans / Final version of the manuscript published in : Plant Cell Reports, 2011, OnlineFirst, DOI: 10.1007/s00299-011-1174-z

\section{References}

Aarrouf J, Garcin A, Lizzi Y, El Maataoui M (2008) Immunolocalization and histocytopathological effects of Xanthomonas arboricola pv pruni on naturally infected leaf and fruit tissues of peach (Prunus persica L Batsch). J Phytopathology 156:338345

Alpizar E, Dechamp E, Espeout S, Royer M, Lecouls AC, Nicole M, Bertrand B, Lashermes P, Etienne H (2006) Efficient production of Agrobacterium rhizogenes-transformed roots and composite plants for studying gene expression in coffee roots. Plant Cell Rep 25:959-967

Bandyopadhyay M, Jha S, Tepfer D (2007) Changes in morphological phenotypes and withanolidecomposition of Ri-transformed roots of Withania somnifera. Plant Cell Rep 26:599-609

Baranski R, Klocke E, Schumann G (2006) Green fluorescent protein as an efficient selection marker for Agrobacterium rhizogenes mediated carrot transformation. Plant Cell Rep 25:190-197

Bevan M (1984) Binary Agrobacterium vectors for plant transformation. Nucleic Acids Res 12:8711-8721

Black LL, Green SK, Hartman G.L, Poulos JM (1991) Pepper diseases: a field guide. In: Asian Vegetable Research and Development Center. AVRDC publication pp 98

Bonnet J, Danan S, Boudet C, Barchi L, Sage-Palloix AM, Caromel B, Palloix A, Lefebvre V (2007) Are the polygenic architectures of resistance to Phytophthora capsici and $P$. parasitica independent in pepper? TAG Theoretical and Applied Genetics 115:253264

Cai D, Kleine M, Kifle S, Harloff HJ, Sandal NN, Marcker KA, Klein-Lankhorst RM, Salentijn EMJ, Lange W, Stiekema WJ, Wyss U, Grunler FMW, Jung C (1997) Positional cloning of a gene for nematode resistance in sugar beet. Science 275:832-834

Chattopadhyay T, Roy S, Mitra A, Maiti M K (2011) Development of a transgenic hairy root system in jute (Corchorus capsularis L.) with gusA reporter gene through Agrobacterium rhizogenes mediated co-transformation. Plant Cell Rep 30:485-493

Chilton MD, Tepfer DA, Petit A, David C, Casse-Delbart F, Tempé J (1982) Agrobacterium rhizogenes inserts T-DNA into the genome of the host plant root cells. Nature 295:432434 
Version définitive du manuscrit publié dans / Final version of the manuscript published in : Plant Cell Reports, 2011, OnlineFirst, DOI: 10.1007/s00299-011-1174-Z

Chovelon V, Restier V, Dogimont C, Aarrouf J (2008) Histological study of shoot organogenesis in melon (Cucumis melo L.) after genetic transformation. Pitrat M. (ed): Cucurbitaceae, Proceedings of the IXth EUCARPIA meeting on genetics and breeding of Cucurbitaceae, Avignon (France), May $21-24^{\text {th }}$ pp $633-637$

Christey MC (2001) Use of Ri-mediated transformation for production of transgenic plants. In Vitro Cell Dev Biol Plant 37:687-700

Diouf D, Gherbi H, Prin Y, Franche C, Duhoux E, Bogusz D (1995) Hairy root nodulation of Casuarina glauca: a system for the study of symbiotic gene expression in an actinorrhizal tree. Mol Plant Microbe Interact 8:532-537

Djian-Caporalino C, Pijarowski L, Januel A, Lefebvre V, Daubèze A, Palloix A, Dalmasso A, Abad P (1999) Spectrum of resistance to root-knot nematodes and inheritance of heat-stable resistance in pepper (Capsicum annuum L.). TAG Theoretical and Applied Genetics 99:496-502.

Djian-Caporalino C, Lefebvre V, Sage-Daubèze AM, Palloix A (2007) Capsicum. In: Singh RJ (Ed.). Genetic Resources, Chromosome Engineering, and Crop Improvement, Vol.3 Vegetable Crops. CRC Press, pp. 185-243

Frary A, Hamilton CM (2001) Efficiency and stability of high molecular weight DNA transformation: an analysis in tomato. Transgenic Res 10:121-132

Fu J, Liu H, Li Y, Yu H, Li X, Xiao J, Wang S (2011) Manipulating broad-spectrum disease resistance by suppressing pathogen-induced auxin accumulation in rice. Plant Physiol 155:589-602

Fulton J, Chungwongse J, Tanksley SD (1995) Microprep protocol for extraction of DNA from tomato and herbaceous plants. Plant Mol Biol 13:207-209

Gaudin V, Vrain T, Jouanin L (1994) Bacterial genes modifying hormonal balances in plants. Plant Physiol Biochem 32:11-29

Gherbi H, Nambiar-Veetil M, Zhong C, Félix J , Autran D, Girardin R, Vaissayre V, Auguy F, Bogusz D, Franche C (2008) Post-Transcriptional Gene Silencing in the Root System of the Actinorhizal Tree Allocasuarina verticillata. MPMI 2:518-524

Hamill JD, Lidgett AJ (1997) Hairy root cultures - opportunities and key protocols for studies in metabolic engineering In 'Hairy roots culture and applications' (Ed PM Doran), Harwood Academic Publishers, Amsterdam, p 239

Hamilton CM (1997) A binary-BAC system for plant transformation with high-molecularweight DNA. Gene 200:107-116 
Version définitive du manuscrit publié dans / Final version of the manuscript published in : Plant Cell Reports, 2011, OnlineFirst, DOI: 10.1007/s00299-011-1174-Z

Hwang CF, Bhakta AV, Truesdell GM, Pudlo WM, Williamson VM (2000) Evidence for a role of the $\mathrm{N}$ terminus and leucine-rich repeat region of the $M i$ gene product in regulation of localized cell death. Plant cell 12:1319-1329

Jefferson R (1987) Assaying chimeric genes in plants: the GUS gene fusion system. Plant Mol Biol Rep 5:387-405

Jouanin L, Tourneur J, Casse-Delbart F (1986) Restriction maps and homologies of the three plasmids of Agrobacterium rhizogenes strain A4. Plasmid 16:124-134

Kazan K, Manners JM (2009) Linking development to defense: auxin in plant-pathogen interactions. Trends in Plant Sci 14:373-382

Khan MW, Haider SH (1991) Comparative damage potential and reproduction efficiency of Meloidogyne javanica and races of $M$. incognita on tomato and eggplant. Nematologica 37:293-303

Kifle S, Shao M, Jung C, Cai D (1999) An improved transformation protocol for studying gene expression in hairy roots of sugar beet (Beta vulgaris L). Plant Cell Rep 18:514519

Kumagai H, Kouchi H (2003) Gene silencing by expression of hairpin RNA in Lotus japonicus roots and root nodules. Mol Plant-Microbe Interact 16:663-668

Kumar V, Satyanarayana KV, Itty SS, Indu EP, Giridhar P, Chandrashekar A, Ravishankar GA (2005) Stable transformation and direct regeneration in Coffea canephora P ex. Fr. by Agrobacterium rhizogenes mediated transformation without hairy-root phenotype. Plant Cell Rep 25:214-222

Murashige T, Skoog F (1962) A revised medium for rapid growth and bio assays with tobacco t cultures. Physiol Plant 15:473-497

Nilsson O, Olsson O (1997) Getting to the root: the role of the Agrobacterium rhizogenes rol genes in formation of hairy root. Physiol Plant 100:403-473

Niwa Y, Hirano T, Yoshimoto K, Shimizu M, Kobayashi H (1999) Non-invasive quantitative detection and applications of non-toxic S65T-type green fluorescent protein in living plants. Plant J 18:455-463

Oldacres AM, Newbury HJ, Puddephat IJ (2005) Identification and characterization of QTL controlling Agrobacterium-mediated transient and stable transformation of Brassica oleracea. Plant Biotechnol J 1:59-69

Pegard A, Brizzard G, Fazari A., Soucaze O, Abad P, and Djian-Caporalino C (2004) Histological Characterization of Resistance to Different Root-Knot Nematode Species Related to Phenolics Accumulation in Capsicum annuum. Nematology 95:158-165 


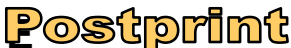

Version définitive du manuscrit publié dans / Final version of the manuscript published in : Plant Cell Reports, 2011, OnlineFirst, DOI: 10.1007/s00299-011-1174-z

R version 2.9.0, Copyright (C) The R Foundation for Statistical Computing (2009) ISBN 3900051-07-0

Remeeus PM, van Bezooijen J, Wijbrandi J, van Bezooijen J (1998) In vitro testing is a reliable way to screen the temperature sensitivity of resistant tomatoes against Meloidogyne incognita. In: Proceedings of 5th international symposium on crop protection Universiteit Gent Belgium 63:635-640

Rizzo DM, Garbelotto M, Hansen EM (2005) Phytophthora ramorum: integrative research and management of an emerging pathogen in California and Oregon forests. Annu Rev Phytopathol 43:309-335

Sasser, JN (1977) Worldwide dissemination and importance of the rootknot nematode, Meloidogyne spp. J Nematol 22:585-589

Schmidt JF, Moore MD, Pelcher LE (2007) High efficiency Agrobacterium rhizogenesmediated transformation of Saponaria vaccaria L. (caryophyllaceae) using fluorescence selection. Plant Cell Rep 26:1547-1554

Sekiguchi S, Yamakawa T, Kodama T,. Smith SM, Yeoman MM (1996) Establishment of Hairy Root Culture of Chilli Pepper (Capsicum frutescens), Plant Tiss Cult Ltt. 13:219221

Shahin EA, Spielmann A, Sukhapinda K, Simpson RB, Yashar M (1986) Transformation of cultivated alfalfa using disarmed Agrobacterium tumefaciens. Crop Science. 26:12351239

Spiral J, Thierry C, Paillard M, Pétiad V (1993) Obtention de plantules de Coffea canephora Pierre (Robusta) transformées par Agrobacterium rhizogenes. CR Acad Sci Paris 316:16

Tepfer M, Casse-Delbart F (1987) Agrobacterium rhizogenes as a vector for transforming higher plants. Microbiological Sci 4: 24-28

Tepfer D (1990) Genetic transformation using Agrobacterium rhizogenes Physiol. Plant 79:140-146

Terada R, Shimamoto K (1990) Expression of CaMV35S-GUS gene in transgenic rice plants. Mol Gen Genet 220:389-392

Wolf D, Matzevitch T, Steinitz B, Zelcer A (2001) Why is it difficult to obtain transgenic pepper plants? Acta Hortic. 560: 229-233

Yamakawa T, Sekigushi S, Kodama T, Smith SM, Yeoman MM (1998) Transformation of chilli pepper (Capsicum frutescens) with a Phenylalanine Ammonia-Lyase gene. Plant Biotechnology 15:189-193 
Version définitive du manuscrit publié dans / Final version of the manuscript published in : Plant Cell Reports, 2011, OnlineFirst, DOI: 10.1007/s00299-011-1174-z

Fig. 1 Hypocotyl (Hyp) and foliar (Fo) explants of Yolo Wonder (YW) and Criollo de Morelos 334 (CM334) genotypes, after 10 weeks of after transformation with A4RSpBIN19-gus and A4RSpHKN29-gfp A.rhizogenes. A: The root expressing GFP fluorescence appears in bright blue-green colour, whereas the explant not expressing GFP fluorescence appears in red. B: Dark blue reveals GUS staining. C: Histological image of a transversal section of an A. rhizogenes-infected hypocotyl explant stained with Toluidine Blue. Radial organization showing the Epidermis (E), Cortical Parenchyma (CP) and Vascular Cylinder (VC). This radial section shows an Adventitious Root Primordium (ARP) developing opposite the xylem pole. D and G Roots issued from the transformation of foliar explants with A4RS-pBIN19-gus. $\mathbf{E}$ and $\mathbf{H}$ Roots issued from the transformation of foliar explants with A4RSpHKN29-gfp. F and I: Uninfected hypocotyl and foliar explants of YW and CM334 genotypes. Spontaneous roots developed only from hypocotyl explants. Bars $=5 \mathrm{~mm}$ (A and $B), B a r=40 \mu \mathrm{m}(C)$.

Fig.2 Initiation and development of transformed hairy roots in foliar explants after inoculation with A4RS-pBIN19-gus or A4RSpHKN29-gfp. A, B, C and D: $\beta$ glucuronidase histochemical staining of YW and CM334 hairy roots after one, five and ten weeks of coculture. E, F, G and H: GFP fluorescence as a marker for genetically co-transformedation roots of YW and CM334 root after one, five and ten weeks of co-culture. Bars $=5 \mathrm{~mm}$.

Fig. 3 PCR screening for rol, vir and gfp genes on twelve transformed hairy roots from YW and CM334, expressing $\left(^{*}\right)$ or not $(\mathbf{x})$ the GFP fluorescence. A4RS-pHKN29-gfp A. rhizogenes (A.r) was used as a positive control.

Fig. 4 Evolution of the necrosis length necroses (in $\mathrm{mm}$ ) on PCR confirmed A4RSpHKN29-gfp A. rhizogenes co-transformed and adventitious untransformed (control) roots of YW and CM334 host genotypes during 6 days after inoculation by P. capsici. Error bars represent confidence intervals of the calculated means using 30 independent measurements of root necrosis length.

Fig. 5 Histological images of longitudinal section of YW and CM334 co-transformed roots inoculated by P. capsici at 24, 48 and 72 hpi. Periodic acid Schiff's reagent (PAS) and naphthol blue black procedures were used to stain and to visualize polysaccharides (pink) 


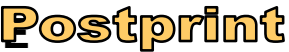

Version définitive du manuscrit publié dans / Final version of the manuscript published in : Plant Cell Reports, 2011, OnlineFirst, DOI: 10.1007/s00299-011-1174-z

and proteins (blue), respectively. Arrows indicate hyphae and haustoria observed in YW at 24 and 48 hpi respectively. The asterisk indicates plasmolysed cells in $\mathrm{YW}$ at $72 \mathrm{hpi}$. Bars = $50 \mu \mathrm{m}$. 